\title{
Comparison of pre- and postoperative techniques in the assessment of histological tumor grading in patients with endometrial carcinoma: a descriptive cross-sectional study
}

\author{
Porównanie przed- i pooperacyjnych technik oceny histologicznego stopnia złośliwości \\ nowotworu u chorych na raka endometrium: przekrojowe badanie opisowe
}

\author{
1 Department of Gynecology and Obstetrics, Health Sciences University, Kocaeli Derince Training and Research Hospital, Kocaeli, Turkey \\ ${ }^{2}$ Kharkiv Medical Academy of Postgraduate Education, Kharkiv, Ukraine \\ Correspondence: Igor Victorovich Lakhno, MD, PhD, DSc, professor of perinatology, obstetrics and gynecology department of Kharkiv Medical Academy of Postgraduate Education, Kharkiv Medical Academy \\ of Postgraduate Education, 61176, Ukraine, Kharkiv, Amosova str., 58, fax: +38(057) 711-80-25, tel.: +38(095) 534-72-08, e-mail: igorlakhno71@gmail.com; Dr. Kemine Uzel, Department of Gynecology \\ and Obstetrics, Health Sciences University, Kocaeli Derince Training and Research Hospital, Kocaeli, Turkey, tel.: +90541 314 25 10, e-mail: kemineuzel@hotmail.com
}

\begin{abstract}
Introduction: This study aimed to compare histological grades in patients with endometrial cancer assessed by pre- and postoperative techniques. Methods: We retrospectively reviewed the records of 43 patients operated on for endometrial cancer between 2012 and 2019. The primary dependent variables included histological grade assessed by preoperative probe curettage and postoperative analysis of surgical specimens. The independent variables included age, surgery type (laparoscopy or laparotomy), pre- and postoperative hemoglobin levels, and the length of hospital stay. Results: The mean age was $62.14 \pm 9.14$ years, and the length of hospitalization time was $6.51 \pm 3.46$ days. The mean values of pre- and postoperative hemoglobin levels were $12.44 \pm 1.51 \mathrm{mg} / \mathrm{dL}$ and $10.91 \pm 1.28 \mathrm{mg} / \mathrm{dL}$, respectively. According to the grading results of probe curettage, grade 1,2 , and 3 tumors were found in 21 (48.8\%), 19 (44.2\%), and 3 (7.0\%) patients, whereas the paraffin sections revealed grade 1,2, and 3 in $12(27.9 \%), 22(51.2 \%)$, and $9(20.9 \%)$ patients, respectively. There was a fair but statistically significant agreement between the pre- and postoperative grading (kappa $=\mathbf{0 . 3 6 5}, \boldsymbol{p}=\mathbf{0 . 0 0 1}$ ). Discussion: This study confirms literature reports that preoperative histological tumor grade fairly predicts final histological results. Caution is warranted when making clinical decisions solely based on probe curettage. Further improvements in preoperative diagnostic techniques in endometrial cancer are needed.
\end{abstract}

Keywords: endometrial cancer, curettage, diagnostic techniques and procedures

Streszczenie Wstęp: Celem badania było porównanie stopnia złośliwości histologicznej nowotworu u chorych na raka endometrium, ocenianego z zastosowaniem metod przed- i pooperacyjnych. Metoda: Analizą retrospektywną objęto dokumentację medyczną 43 pacjentek operowanych w latach 2012-2019 z powodu raka endometrium. Głównymi zmiennymi zależnymi były stopnie złośliwości histologicznej oceniane na podstawie wyników uzyskanych po przedoperacyjnym wyłyżeczkowaniu jamy macicy lub pooperacyjnie na podstawie próbek pobranych podczas zabiegu. Zmienne niezależne obejmowały wiek, typ zabiegu (laparoskopia lub laparotomia), przed- i pooperacyjne stężenie hemoglobiny oraz długość pobytu w szpitalu. Wyniki: Średnia wieku wyniosła $62,14 \pm 9,14$ roku, natomiast długość hospitalizacji 6,51 $\pm 3,46$ dnia. Średnie wartości przed-i pooperacyjnego stężenia hemoglobiny wynosiły odpowiednio $12,44 \pm 1,51 \mathrm{mg} / \mathrm{dl}$ i $10,91 \pm 1,28 \mathrm{mg} / \mathrm{dl}$. Zgodnie z wynikami uzyskanymi po wyłyżeczkowaniu jamy macicy stopnie G1, G2 i G3 stwierdzono odpowiednio u 21 (48,8\%), 19 (44,2\%) i 3 (7,0\%) pacjentek, podczas gdy analiza skrawków parafinowych ujawniła stopnie G1, G2 i G3 odpowiednio u 12 (27,9\%), 22 (51,2\%) i 9 (20,9\%) pacjentek. Odnotowano przeciętną (współczynnik kappa $=\mathbf{0 , 3 6 5})$, ale istotną statystycznie $(\boldsymbol{p}=\mathbf{0 , 0 0 1})$ zgodność między oceną przed- i pooperacyjną. Omówienie: Wyniki badania potwierdzają dane z piśmiennictwa wskazujące, że przedoperacyjna ocena stopnia złośliwości histologicznej nowotworu przeciętnie dokładnie przewiduje ostateczne wyniki badania histopatologicznego. Należy zachować ostrożność przy podejmowaniu decyzji jedynie w oparciu o rezultaty uzyskane w wyniku abrazji jamy macicy. Niezbędne są dalsze udoskonalenia w zakresie przedoperacyjnych metod diagnostycznych stosowanych u chorych na raka endometrium.

Słowa kluczowe: rak endometrium, wyłyżeczkowanie jamy macicy, metody i procedury diagnostyczne 


\section{INTRODUCTION}

$\mathrm{E}$ ndometrial cancer (EC) is one of the most common malignancies in women, especially in Western countries. It is responsible for 6-9\% of all cancer types in females and mainly occurs in postmenopausal women at the age of 50-65 years ${ }^{(1,2)}$. The majority of patients (approximately $80 \%$ ) have stage-1 endometrial carcinoma due to the early symptoms such as postmenopausal or abnormal uterine bleeding ${ }^{(3)}$. On the other hand, the incidence of EC is systematically increasing, and there are some crucial risk factors, including obesity, diabetes, late menopause, uncontrolled use of estrogens, tamoxifen for breast cancer, and $\operatorname{aging}^{(4,5)}$.

Serum tumor markers such as CA-125, CA-15-3, and CA-19-9 are defined as cancer antigens, and are observed in some disorders, including $\mathrm{EC}^{(6)}$. Carbohydrate antigen 125 (CA-125) is the most known and used serum marker, which is found in $80 \%$ of patients with EC. Thresholds of $35 \mathrm{U} / \mathrm{mL}^{(7,8)}$ and $20 \mathrm{U} / \mathrm{mL}^{(9)}$ have been suggested. Carbohydrate antigen 19-9 (CA-19-9) is known as a monoclonal antibody, which is increased in some types of cancers ${ }^{(7,10)}$. The CA-19-9 threshold is $37 \mathrm{U} / \mathrm{mL}$ in healthy individuals. On the other hand, cancer antigen 15-3 (CA-15-3) is a murine monoclonal antibody associated with cancer; its threshold is given as $32 \mathrm{U} / \mathrm{mL}^{(7,11)}$.

The stage of EC, serum markers, the depth of myometrial invasion, and the histological grade are the most critical factors for determining the prognosis and treatment. Pelvic and paraaortic lymph node metastases are directly proportional to the depth and histological grade of myometrial invasion $^{(12)}$. These prognostic factors should be evaluated in the preoperative period to determine an appropriate treatment protocol. For example, in addition to total abdominal hysterectomy (TAH) and bilateral salpingo-oophorectomy (BSO), lymph node dissections (LND) are also performed through a vertical midline incision in patients with deep myometrial invasion and high histological grade. Furthermore, preoperative radiotherapy can be used in some patients. While the histology and grade of EC can be determined by endometrial biopsy or diagnostic curettage in the preoperative period, the depth of myometrial invasion of the tumor can only be evaluated by imaging methods or postoperative histopathological examinations ${ }^{(12-14)}$.

The first-choice treatment for early-stage endometrial cancer is TAH and $\mathrm{BSO}^{(15)}$. Although accepted as an effective and preferred treatment option, it is not adequate for patients who are at risk of lymph node metastasis. Besides, it is highly invasive and has several adverse effects, including blood loss and wound problems ${ }^{(16)}$. An alternative approach for these patients is laparoscopy, which is a less invasive technique. Related retrospective and prospective studies reported that the laparoscopic approach is an effective and safe alternative with shorter hospital stay, reduced mortality and morbidity, and less pain in patients with early-stage $\mathrm{EC}^{(17-20)}$.

\section{OBJECTIVES}

In this study, we aimed to compare the histological grades in patients with endometrial cancer determined by preoperative probe curettage and postoperative paraffin pathology techniques after total laparoscopic and total abdominal hysterectomy surgeries.

\section{MATERIALS AND METHODS}

\section{Ethical approval}

The necessary permissions were obtained from the Clinical Research Ethics Committee of Kharkiv Medical Academy of Postgraduate Education, No 41.0619p. The study was conducted in accordance with the Declaration of Helsinki. Study reporting was done following the STROBE guidelines ${ }^{(21)}$.

\section{Study design}

In this study, we retrospectively reviewed the records of 77 patients with endometrial cancer who had been subjected to surgery between 2012 and 2019. During the study period, 43 patients had single or combined surgeries including total laparoscopic hysterectomy (TLH) and TAH as well as $\mathrm{BSO}$, pelvic paraaortic lymph node dissection, appendectomy, omentectomy, and left/right hypogastric artery ligation. EC stage diagnosed by endometrial aspiration or curettage was the main eligibility criterion for a laparoscopic surgery. All patients had their initial diagnosis made by probe curettage and had undergone hysterectomy. After hysterectomy, surgical samples were evaluated in the department of pathology for tumor histology, cancer types, and histological grade.

\section{Participants}

Seventy-seven endometrial cancer patients were included in the study. Six patients whose pathology results were not recorded in the patient files were excluded $(n=71)$.

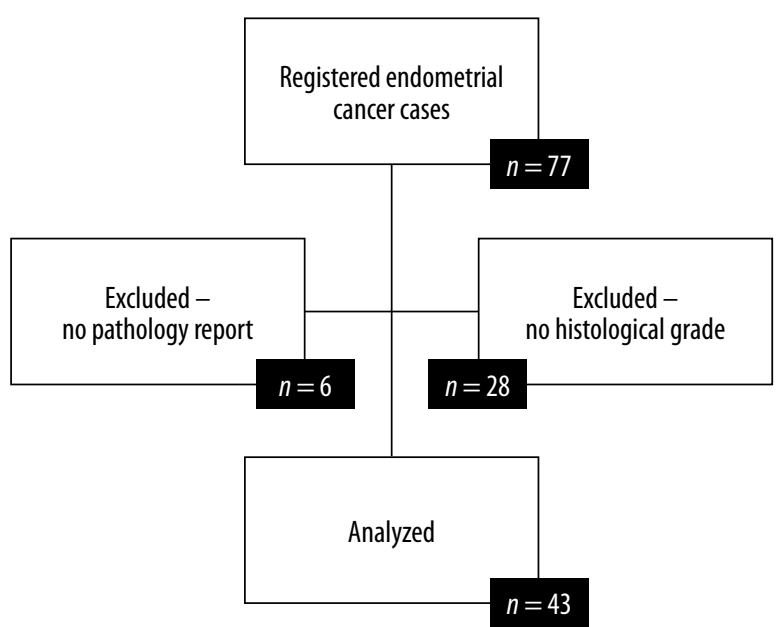

Fig. 1. Study flow diagram 
Twenty-eight patients whose histological grades were not available were also excluded. The final study population consisted of 43 patients with EC (Fig. 1). Of the 43 endometrial cancer patients, 40 (93.0\%) had endometrial adenocarcinoma, 2 (4.7\%) had clear cell carcinoma, and 1 (2.3\%) had adenosquamous carcinoma.

\section{Variables}

The primary dependent variables were histological grade assessed by preoperative probe curettage and postoperative analysis of surgical specimens. Other variables assessed included age, surgery type (laparoscopy or laparotomy), serum tumor markers (CA-125, CA-15-3, and CA-19-9), pre- and postoperative hemoglobin values, and the length of hospital stay (LOS).

\section{Statistical analysis}

Data were analyzed using the Statistical Package for the Social Sciences (SPSS) version 22.0 software (SPSS Inc., Chicago, IL, USA). The "number (n)," "percentage (\%)," "mean," "standard deviation $(S D)$," median, minimum and maximum values were given for the descriptive statistics. The independent samples $t$-test or Mann-Whitney $U$ test were used to compare numerical variables. Statistical differences between more than two groups were determined with the one-way ANOVA test. The Pearson chi-square or Fisher's exact test was used to analyze categorical data. Pearson correlation was used to search for relationships between scale variables. Agreements of the pre- and postoperative histological grading were calculated by Cohen's kappa coefficient. The level of significance $(p)$ was set at 0.05 .

\section{RESULTS}

Data for 43 patients with EC were analyzed. The mean age of patients was $62.14 \pm 9.14$ years (median: 63, minimum: 47, maximum: 84). The mean LOS was $6.51 \pm 3.46$ days. Mean values of pre- and postoperative hemoglobin levels were $12.44 \pm 1.51 \mathrm{mg} / \mathrm{dL}$ and $10.91 \pm 1.28 \mathrm{mg} / \mathrm{dL}$, respectively. There was a significant correlation between pre- and postoperative hemoglobin values $(r=0.704 ; \boldsymbol{p}<\mathbf{0 . 0 0 1})$.

According to the grading results from probe curettage, grade 1,2 , and 3 distribution was 21 (48.8\%), 19 (44.2\%), and $3(7.0 \%)$, respectively. On the other hand, grading results from paraffin sections indicated grade 1, 2 and 3 in $12(27.9 \%), 22(51.2 \%)$, and $9(20.9 \%)$ patients, respectively.

\begin{tabular}{|l|c|c|c|c|c|c|}
\hline \multirow{2}{*}{$\begin{array}{l}\text { Probe } \\
\text { curettage }\end{array}$} & \multicolumn{3}{|c|}{ Paraffin section } & \multirow{2}{*}{ Total } & \multirow{2}{*}{ Kappa } & \multirow{2}{*}{$\boldsymbol{p}$} \\
\cline { 2 - 5 } & Grade 1 & Grade 2 & Grade 3 & & & \\
\hline Grade 1 & 11 & 8 & 2 & 21 & & \\
Grade 2 & 1 & 13 & 5 & 19 & 0.365 & $\mathbf{0 . 0 0 1}$ \\
Grade 3 & 0 & 1 & 2 & 3 & & \\
\hline Total & 12 & 22 & 9 & 43 & & \\
\hline
\end{tabular}

Tab. 1. Comparison of pre- and postoperative grading results

\begin{tabular}{|l|c|c|c|c|c|c|}
\hline \multirow{2}{*}{$\begin{array}{l}\text { Probe } \\
\text { curettage }\end{array}$} & \multicolumn{3}{|c|}{ Paraffin section } & \multirow{2}{*}{ Total } & \multirow{2}{*}{ Kappa } & $\boldsymbol{p}$ \\
\cline { 2 - 6 } & Grade 1 & Grade 2 & Grade 3 & & & \\
\hline Grade 1 & 8 & 7 & 2 & 17 & & \\
Grade 2 & 0 & 8 & 2 & 10 & 0.413 & $\mathbf{0 . 0 0 1}$ \\
Grade 3 & 0 & 0 & 2 & 2 & & \\
\hline Total & 8 & 15 & 6 & 29 & & \\
\hline
\end{tabular}

Tab. 2. Comparison of preoperative and TLH laparoscopy grading results

\begin{tabular}{|l|c|c|c|c|c|c|}
\hline \multirow{2}{*}{$\begin{array}{l}\text { Probe } \\
\text { curettage }\end{array}$} & \multicolumn{3}{|c|}{ Paraffin section } & \multirow{2}{*}{ Total } & \multirow{2}{*}{ Kappa } & $\boldsymbol{p}$ \\
\cline { 2 - 7 } & Grade 1 & Grade 2 & Grade 3 & & & \\
\hline Grade 1 & 3 & 1 & 0 & 4 & & \\
Grade 2 & 1 & 5 & 3 & 9 & 0.263 & 0.223 \\
Grade 3 & 0 & 1 & 0 & 1 & & \\
\hline Total & 4 & 7 & 3 & 14 & & \\
\hline
\end{tabular}

Tab. 3. Comparison of preoperative and TAH laparoscopy grading results

There was a fair but statistically significant agreement between the pre- and postoperative grading results $(\mathbf{k a p p a}=\mathbf{0 . 3 6 5}, \boldsymbol{p}=\mathbf{0 . 0 0 1})($ Tab. 1$)$.

When the histological grades detected by curettage and paraffin section after TLH surgery were compared, again a fair but significant agreement was found between probe curettage and paraffin grading (kappa $=\mathbf{0 . 4 1 3}, \boldsymbol{p}=\mathbf{0 . 0 0 1})(\mathrm{Tab} .2)$. We performed another analysis to compare histological grades determined based on probe curettage and paraffin section after TAH surgery, which demonstrated no agreement between probe curettage and paraffin grading (kappa: $0.263, p=0.223$ ) (Tab. 3).

The mean values of serum markers (CA-125, CA-15-3, and CA-19-9) were $18.00 \pm 17.63 \mathrm{U} / \mathrm{mL}, 13.32 \pm 7.70 \mathrm{U} / \mathrm{mL}$, and $16.56 \pm 19.02 \mathrm{U} / \mathrm{mL}$, respectively. Although 9 patients (21\%) had high CA-125 levels, the mean values of all patients were within normal limits. On the other hand, one of the 43 patients had high CA-19-9, while all patients had normal CA-15-3 levels. Besides, the mean CA-15-3 and CA-19-9 levels were below the threshold in all EC grades. Also, the mean serum CA-125 levels were normal in patients with grade 1 and grade $2 \mathrm{EC}$, whereas they were above the threshold in patients with grade $3 \mathrm{EC}$ (Tab. 4). There were no statistically significant differences in CA-125 $(F=0.298, p=0.744)$, CA-15-3 $(F=0.906, p=0.413)$, or CA-19-9 $(F=0.585$, $p=0.562)$ levels between endometrial carcinoma grades.

Additionally, we compared the surgery types in terms of age, hemoglobin values, LOS, and histological grade. There were no statistically significant differences for age, pre- and postoperative hemoglobin values between patients who were

\begin{tabular}{|l|c|c|c|}
\hline & CA-125 & CA-15-3 & CA-19-9 \\
\hline Grade 1 & $15.33 \pm 14.64$ & $11.50 \pm 5.03$ & $15.08 \pm 9.83$ \\
\hline Grade 2 & $18.05 \pm 18.85$ & $13.15 \pm 8.56$ & $19.65 \pm 25.56$ \\
\hline Grade 3 & $21.44 \pm 19.79^{*}$ & $16.11 \pm 8.96$ & $11.67 \pm 8.41$ \\
\hline * Above the threshold for normal. \\
\hline
\end{tabular}

Tab. 4. The mean values of serum markers in patients with EC 


\begin{tabular}{|l|c|c|c|c|}
\hline & $\begin{array}{c}\text { Laparoscopy } \\
\text { (TLH) } \\
\boldsymbol{n}=\mathbf{2 9}\end{array}$ & $\begin{array}{c}\text { Laparotomy } \\
\text { (TAH) } \\
\boldsymbol{n}=\mathbf{1 4}\end{array}$ & \multirow{2}{*}{ Z/ $\mathbf{X}^{\mathbf{2}}$} & $\boldsymbol{p}$ \\
\cline { 2 - 4 } & Mean \pm SD & Mean \pm SD & & \\
\hline Age (years) & $61.90 \pm 8.92$ & $62.64 \pm 9.91$ & -0.208 & 0.835 \\
\hline $\begin{array}{l}\text { Preoperative } \\
\text { hemoglobin (g/dL) }\end{array}$ & $12.35 \pm 1.56$ & $12.64 \pm 1.44$ & -0.536 & 0.592 \\
\hline $\begin{array}{l}\text { Postoperative } \\
\text { hemoglobin (g/dL) }\end{array}$ & $10.90 \pm 1.37$ & $10.93 \pm 1.14$ & -0.160 & 0.873 \\
\hline $\begin{array}{l}\text { Length of } \\
\text { hospitalization (days) }\end{array}$ & $5.83 \pm 3.60$ & $7.93 \pm 2.73$ & -2.649 & $\mathbf{0 . 0 0 8 *}$ \\
\hline $\begin{array}{l}\text { Paraffin section report } \\
\text { Grade 1 } \\
\text { Grade 2 } \\
\text { Grade 3 }\end{array}$ & $\begin{array}{c}8(27.6 \%) \\
15(51.7 \%)\end{array}$ & $\begin{array}{c}4(28.6 \%) \\
7(50.0 \%)\end{array}$ & 0.011 & 1.000 \\
\hline $\begin{array}{l}\text { * Mann-Whitney U test. } \\
\text { SD - standard deviation. }\end{array}$ & & & \\
\hline
\end{tabular}

Tab. 5. Characteristics of patients with endometrial cancer by the type of surgery

subjected to TLH or TAH surgery $(Z=-0.208, p=0.835$; $Z=-0.536, p=0.592$; and $Z=-0.160, p=0.873$, respectively). However, a significant difference was detected between these groups for the length of hospitalization $(Z=-\mathbf{2 . 6 4 9}$, $p=0.008$ ). Patients after TLH stayed in the hospital for approximately 6 days, while those subjected to TAH were hospitalized for around 8 days. No statistically significant differences were detected between TLH and TAH surgeries regarding the paraffin section reports $(Z=0.011, p=1.000)$ or histological results $(Z=2.129, p=0.793)$ (Tab. 5).

\section{DISCUSSION}

Endometrial cancer is the most common gynecologic malignancy in developed countries. Approximately 40,000 new cases are diagnosed each year, and early detection of $80 \%$ of the cases is probably the reason for the overall good prognosis ${ }^{(22)}$. An accurate preoperative assessment is imperative for the patients, which will allow the planning of surgery and therapy ${ }^{(23)}$. This study demonstrated that there is a fair comparison between pre- and postoperative grading techniques in patients with EC.

The overall diagnostic accuracy of preoperative curettage was reported as ranging between $35 \%$ and $96 \%{ }^{(24-26)}$. We retrospectively found 43 patients with EC who had both pre- (curettage) and postoperative (surgery) results. The comparison of curettage- and surgery-based histological grades in EC patients showed a statistically significant but fair agreements between the two diagnostic methods. The concordance between these methods was $61 \%$ in our study. However, Acikalin et al. ${ }^{(16)}$ reported this rate as $84.3 \%$. The highest agreement was in grade $2(13 / 19,68 \%)$, followed by grade $3(2 / 3,66 \%)$, and grade $1(11 / 21,52 \%)$. We detected a discrepancy of $39 \%$ (17/43), overgrading of $35 \%$, and undergrading of $5 \%$ preoperative grading results when compared to post-operative results. Looking at the data in the literature, our findings are close to those of Larson et al. ${ }^{(27)}$

\begin{tabular}{|c|c|c|c|}
\hline \multirow[b]{2}{*}{ Authors } & \multirow[b]{2}{*}{ Year } & \multicolumn{2}{|c|}{ Preoperative grading } \\
\hline & & $\begin{array}{c}\text { Discrepant } \\
(\%)\end{array}$ & $\begin{array}{c}\text { Upgrade } \\
(\%)\end{array}$ \\
\hline Daniel and Peters ${ }^{(29)}$ & 1988 & $28(31)$ & $17(11)$ \\
\hline Zorlu et al..$^{(30)}$ & 1994 & $2(7)$ & $1(4)$ \\
\hline Larson et al..$^{(27)}$ & 1995 & $9(24)$ & $5(14)$ \\
\hline Frumovitz et al. ${ }^{(28)}$ & 2004 & $23(27)$ & $19(23)$ \\
\hline Stephan et al. ${ }^{(31)}$ & 2014 & $24(29)$ & $4(5)$ \\
\hline Current study & 2019 & $17(39)$ & $15(35)$ \\
\hline
\end{tabular}

Tab. 6. Preoperative grading versus final histological results in diagnosing endometrial cancer grade: summary of published series

and Frumovitz et al. ${ }^{(28)}$ (Tab. 6). At this point, we can say that the results of our study also confirm previous findings that preoperative histological tumor grade does not predict final histological results with high accuracy.

On the other hand, many centers in the world have moved away from using the preoperative method, focusing more on intraoperative or postoperative techniques ${ }^{(31)}$. Having said that, laparotomy has generally been preferred. However, laparoscopy is a less-invasive, effective, and safe alternative to laparotomy. Hence, its utilization in patients with EC is increasing ${ }^{(25)}$. Also, factors such as hemoglobin, operative time, body mass index, LOS, and postoperative complaints are important for the therapy.

In our study, 29 patients were subjected to TLH, while 14 patients received TAH. When the histological tumor grades were compared to preoperative results, it was seen that there was a statistically significant difference between the TLH groups, whereas no significant difference was detected in patients receiving TAH. On the other hand, we compared the surgical techniques for tumor grades. No statistically significant difference was detected between TLH and TAH, considering the final pathology results. However, there is a dilemma concerning the use of surgical methods for EC patients ${ }^{(32,33)}$. For this reason, some studies were performed to identify advantages of these surgical techniques. We evaluated this issue by comparing only two parameters.

The mean hemoglobin decline after surgical intervention in TLH and TAH patients was $1.54 \mathrm{~g} / \mathrm{dL}$ and $1.57 \mathrm{~g} / \mathrm{dL}$, respectively. For comparison, no such difference was detected between TAH and TLH. However, Malzoni et al. ${ }^{(34)}$ reported a significant difference between TAH and TLH in terms of hemoglobin drops $(1.1 \mathrm{~g} / \mathrm{dL}$ and $0.4 \mathrm{~g} / \mathrm{dL}$, respectively). Also, Seracchioli et al. ${ }^{(35)}$ reported a higher hemoglobin drop in TAH patients $(2.3 \mathrm{~g} / \mathrm{dL})$.

Moreover, the LOS is a chief factor for EC patients. From this perspective, our findings were in line with the current literature. Zullo et al. ${ }^{(20)}$ reported that LOS in TLH and TAH patients was 4.1 and 8.2 days, respectively. Similarly, Obermair et al. ${ }^{(33)}$, Bell et al. ${ }^{(36)}$, Frigerio et al. ${ }^{(37)}$, Soliman et al. ${ }^{(38)}$, Ghezzi et al. ${ }^{(39)}$, and Malzoni et al. ${ }^{(34)}$ reported that TAH patients had a shorter LOS than TLH patients. The reduced hospital stay in TLH patients indicates lower cost and rapid recovery. 
Serum markers such as CA-125, CA-15-3, and CA-19-9 may be a useful to predict endometrial cancer preoperatively ${ }^{(40,41)}$. Panidis et al. ${ }^{(6)}$ reported that mean serum CA-125, CA-15-3, and CA-19-9 values were 56.8, 43.1, and 30.1, respectively. Additionally, Ghosh et al. ${ }^{(7)}$ also reported that all serum cancer antigens were above the threshold in EC patients. Furthermore, Hsieh et al. ${ }^{(42)}$ found that serum levels of CA-125 were approximately 8-fold higher, especially in patients with positive node metastases. However, our results were in disagreement with the current literature. Except CA-125 levels in patients with grade $3 \mathrm{EC}$, all serum marker levels were below the threshold. Lower levels of serum markers may be related to the number of lymph node metastases in our patients.

\section{LIMITATIONS}

Our study has some limitations. First, it has the drawbacks of retrospective studies; almost half of the patients had to be excluded due to missing data. Second, measurement of some other parameters, such as the amount of blood loss, operative time, postoperative complications, and FIGO staging, would have contributed to interpreting the outcomes. Third, the intraoperative and postoperative serum levels of cancer antigens should be measured to perform a better comparison. Lastly, the study population is limited to one hospital, and, thus, caution is suggested in generalizing the findings.

\section{CONCLUSION}

This study confirms literature reports indicating that preoperative histological tumor grade fairly predicts final histological results. Caution is warranted when taking clinical decisions solely based on probe curettage. Further improvements in preoperative diagnostic techniques in endometrial cancer are needed.

\section{Conflict of interest}

The authors have no conflict of interest for this study.

\section{Funding/Support and role of the sponsor}

This research received no specific grant from any funding agency in the public, commercial, or not-for-profit sectors.

\section{References}

1. Bijen CB, Briët JM, de Bock GH et al.: Total laparoscopic hysterectomy versus abdominal hysterectomy in the treatment of patients with early stage endometrial cancer: a randomized multi center study. BMC Cancer 2009; 9: 23.

2. Wang HL, Ren YF, Yang J et al.: Total laparoscopic hysterectomy versus total abdominal hysterectomy for endometrial cancer: a meta-analysis. Asian Pac J Cancer Prev 2013; 14: 2515-2519.

3. Janda M, Gebski V, Brand A et al.: Quality of life after total laparoscopic hysterectomy versus total abdominal hysterectomy for stage I endometrial cancer (LACE): a randomised trial. Lancet Oncol 2010; 11: 772-780.

4. Galaal K, Bryant A, Fisher AD et al.: Laparoscopy versus laparotomy for the management of early stage endometrial cancer. Cochrane Database Syst Rev 2012; (9): CD006655.

5. Colombo N, Creutzberg C, Amant F et al.; ESMO-ESGO-ESTRO Endometrial Consensus Conference Working Group: ESMOESGO-ESTRO Consensus Conference on Endometrial Cancer: diagnosis, treatment and follow-up. Ann Oncol 2016; 27: 16-41.

6. Panidis D, Vlassis G, Matalliotakis J et al.: Serum levels of the oncofetal antigens CA-125, CA 19-9 and CA 15-3 in patients with endometriosis. J Endocrinol Invest 1988; 11: 801-804.

7. Ghosh I, Bhattacharjee D, Das AK et al.: Diagnostic role of tumour markers CEA, CA15-3, CA19-9 and CA125 in lung cancer. Indian J Clin Biochem 2013; 28: 24-29.

8. Powers AC: Diabetes mellitus. In: Fauci AS, Braunwald E, Kasper DL et al. (eds.): Harrison's Principles of Internal Medicine. McGraw Hill, New York 2008: 2275-2304.

9. Lo SST, Cheng DKL, Ng TY et al.: Prognostic significance of tumour markers in endometrial cancer. Tumour Biol 1997; 18: 241-249.

10. Kobayashi T, Xu XW, MacMahon $\mathrm{H}$ et al.: Effect of a computeraided diagnosis scheme on radiologists' performance in detection of lung nodules on radiographs. Radiology 1996; 199: 843-848.

11. Daniel WC, Stewart S: Tumour markers. In: Burtis CA, Ashwood ER (eds.): Tietz Textbook of Clinical Chemistry. $3^{\text {rd }}$ ed., Saunders Elsevier, Philadelphia 1999: 733-737.

12. Eltabbakh GH, Shamonki MI, Moody JM et al.: Hysterectomy for obese women with endometrial cancer: laparoscopy or laparotomy? Gynecol Oncol 2000; 78: 329-335.

13. Berek JS, Hacker NF: Berek and Hacker's Gynecologic Oncology. $5^{\text {th }}$ ed., Lippincott Williams \& Wilkins, Philadelphia 2010.

14. Creasman WT, Odicino F, Maisonneuve P et al.: Carcinoma of the corpus uteri. FIGO $26^{\text {th }}$ Annual Report on the Results of Treatment in Gynecological Cancer. Int J Gynaecol Obstet 2006; 95 Suppl 1: S105-S143.

15. O'Hanlan KA, Huang GS, Garnier AC et al.: Total laparoscopic hysterectomy versus total abdominal hysterectomy: cohort review of patients with uterine neoplasia. JSLS 2005; 9: 277-286.

16. Acikalin A, Gumurdulu D, Bagir EK et al.: The guidance of intraoperative frozen section for staging surgery in endometrial carcinoma: frozen section in endometrial carcinoma. Pathol Oncol Res 2015; 21: 119-122.

17. Garry R, Fountain J, Brown J et al.: EVALUATE hysterectomy trial: a multicentre randomised trial comparing abdominal, vaginal and laparoscopic methods of hysterectomy. Health Technol Assess 2004; 8: 1-154.

18. Scribner DR Jr, Walker JL, Johnson GA et al.: Surgical management of early-stage endometrial cancer in the elderly: is laparoscopy feasible? Gynecol Oncol 2001; 83: 563-568.

19. Tozzi R, Malur S, Koehler C et al.: Analysis of morbidity in patients with endometrial cancer: is there a commitment to offer laparoscopy? Gynecol Oncol 2005; 97: 4-9.

20. Zullo F, Falbo A, Palomba S: Safety of laparoscopy vs laparotomy in the surgical staging of endometrial cancer: a systematic review and metaanalysis of randomized controlled trials. Am J Obstet Gynecol 2012; 207: 94-100.

21. von Elm E, Altman DG, Egger $M$ et al.: The Strengthening the Reporting of Observational Studies in Epidemiology (STROBE) statement: guidelines for reporting observational studies. PLoS Med 2007; 4: e296.

22. Boronow RC: Advances in diagnosis, staging, and management of cervical and endometrial cancer, stages I and II. Cancer 1990; 65 (Suppl): 648-659.

23. Alcázar JL, Jurado M, López-García G: Comparative study of transvaginal ultrasonography and CA 125 in the preoperative evaluation of myometrial invasion in endometrial carcinoma. Ultrasound Obstet Gynecol 1999; 14: 210-214.

24. Sato S, Itamochi $H$, Shimada $M$ et al.: Preoperative and intraoperative assessments of depth of myometrial invasion in endometrial cancer. Int J Gynecol Cancer 2009; 19: 884-887. 


\section{Comparison of pre- and postoperative techniques in the assessment of histological tumor grading \\ in patients with endometrial carcinoma: a descriptive cross-sectional study}

25. Terao Y, Kitade M, Kusunoki S et al.: Surgical and oncological outcome of laparoscopic surgery, compared to laparotomy, for Japanese patients with endometrial cancer. Gynecol Minim Invasive Ther 2016; 5: 64-68.

26. Wang $\mathrm{X}$, Zhang H, Di W et al.: Clinical factors affecting the diagnostic accuracy of assessing dilation and curettage vs frozen section specimens for histologic grade and depth of myometrial invasion in endometrial carcinoma. Am J Obstet Gynecol 2009; 201: 194.e1-194.e10.

27. Larson DM, Johnson KK, Broste SK et al.: Comparison of D\&C and office endometrial biopsy in predicting final histopathologic grade in endometrial cancer. Obstet Gynecol 1995; 86: 38-42.

28. Frumovitz M, Singh DK, Meyer L et al.: Predictors of final histology in patients with endometrial cancer. Gynecol Oncol 2004; 95: 463-468.

29. Daniel AG, Peters WA 3rd: Accuracy of office and operating room curettage in the grading of endometrial carcinoma. Obstet Gynecol 1988; 71: 612-614.

30. Zorlu CG, Cobanoglu O, Işik AZ et al.: Accuracy of pipelle endometrial sampling in endometrial carcinoma. Gynecol Obstet Invest 1994; 38: 272-275.

31. Stephan JM, Hansen J, Samuelson M et al.: Intra-operative frozen section results reliably predict final pathology in endometrial cancer. Gynecol Oncol 2014; 133: 499-505.

32. Karabagli P, Ugras S, Yilmaz BS et al.: The evaluation of reliability and contribution of frozen section pathology to staging endometrioid adenocarcinomas. Arch Gynecol Obstet 2015; 292: 391-397.

33. Obermair A, Manolitsas TP, Leung Y et al.: Total laparoscopic hysterectomy for endometrial cancer: patterns of recurrence and survival. Gynecol Oncol 2004; 92: 789-793.
34. Malzoni M, Tinelli R, Cosentino F et al.: Total laparoscopic hysterectomy versus abdominal hysterectomy with lymphadenectomy for early-stage endometrial cancer: a prospective randomized study. Gynecol Oncol 2009; 112: 126-133.

35. Seracchioli R, Venturoli S, Vianello F et al.: Total laparoscopic hysterectomy compared with abdominal hysterectomy in the presence of a large uterus. J Am Assoc Gynecol Laparosc 2002; 9: 333-338.

36. Bell MC, Torgerson J, Seshadri-Kreaden U et al.: Comparison of outcomes and cost for endometrial cancer staging via traditional laparotomy, standard laparoscopy and robotic techniques. Gynecol Oncol 2008; 111: 407-411.

37. Frigerio L, Gallo A, Ghezzi F et al.: Laparoscopic-assisted vaginal hysterectomy versus abdominal hysterectomy in endometrial cancer. Int J Gynaecol Obstet 2006; 93: 209-213.

38. Soliman HO, Elsebaie HI, Gad ZS et al.: Laparoscopic hysterectomy in the treatment of endometrial cancer: NCI experience. J Egypt Natl Canc Inst 2011; 23: 101-104.

39. Ghezzi F, Cromi A, Bergamini V et al.: Laparoscopic-assisted vaginal hysterectomy versus total laparoscopic hysterectomy for the management of endometrial cancer: a randomized clinical trial. J Minim Invasive Gynecol 2006; 13: 114-120.

40. Dotters DJ: Preoperative CA 125 in endometrial cancer: is it useful? Am J Obstet Gynecol 2000; 182: 1328-1334.

41. Tas EE, Yavuz AF: The prognostic significance of preoperative serum cancer antigen 15-3 levels in endometrial carcinomas. Saudi Med J 2017; 38: 1096-1100.

42. Hsieh $\mathrm{CH}$, ChangChien $\mathrm{CC}$, Lin $\mathrm{H}$ et al:: Can a preoperative CA 125 level be a criterion for full pelvic lymphadenectomy in surgical staging of endometrial cancer? Gynecol Oncol 2002; 86: 28-33. 